\title{
Stan i perspektywy produkcji nasiennej roślin bobowatych grubonasiennych w Polsce
}

\author{
The condition and perspectives of seed production of grain legumes in Poland
}

\author{
Tadeusz Oleksiak $^{\circledast}$, Dagmara Bronisz ${ }^{\oplus}$
}

Instytut Hodowli i Aklimatyzacji Roślin - Państwowy Instytut Badawczy

$\bowtie$ t.oleksiak@ihar.edu.pl

\begin{abstract}
Na podstawie danych o produkcji ziarna i trendów w produkcji nasiennej analizowano stan i perspektywy rynku nasiennego roślin bobowatych grubonasiennych. Przeprowadzono analizę zmian powierzchni upraw, wielkości produkcji w wieloleciu 1990-2019 i oceniono możliwości wzrostu produkcji nasion.
\end{abstract}

\begin{abstract}
Określono udział kwalifikowanego materiału siewnego (KMS) stosowanego w produkcji bobowatych i wielkość zapotrzebowania na materiał siewny w zależności od rozwoju produkcji paszowej wykorzystującej nasiona tych roślin. Uwzględniając ceny materiału siewnego oceniono rzeczywistą oraz potencjalną wartość rynku nasiennego. Oceniono możliwości dalszego rozwoju produkcji nasiennej bobowatych grubonasiennych w zależności od zmieniającego się zapotrzebowania na nasiona roślin bobowatych.
\end{abstract}

Słowa kluczowe: rośliny bobowate grubonasienne, produkcja rolna, rynek nasienny

Based on production data and trends in seed production, the state and prospects of the seed market of grain legumes were analyzed. Changes in the cultivated area and production volume of these plants over the years 1990-2019 were analyzed, together with an assessment of the potential for their seed production growth.

The share of certified seed (CS) used in the production of grain legumes and the demand for seeds in relation to the development of the domestic production of fodder plant protein were determined. Taking into account the prices of seeds, the actual and potential value of the seed market was assessed. The possibilities of further development of grain legume seed production were estimated depending on the changing demand for domestic legume seeds.

Key words: grain legumes, agricultural production, seed market

\section{Wstęp}

O znaczeniu gospodarczym roślin bobowatych grubonasiennych decyduje przede wszystkim wysoka zawartość białka w nasionach. Stanowić mogą one cenny komponent białkowy pożywienia człowieka oraz podstawowe źródło tego surowca do produkcji pasz dla zwierząt. Szczególnie istotne jest to w sytuacji pogłębiającego się deficytu krajowych zasobów pasz wysokobiałkowych. Zdolności wiązania azotu atmosferycznego i dodatni bilans reprodukcji materii organicznej mogą być także czynnikiem odgrywającym znaczącą rolę w produkcji roślinnej, polepszając wartość stanowiska w zmianowaniu. Poprawiają strukturę i zawartość próchnicy w glebie, a ich głęboki system korzeniowy umożliwia pobranie składników, które zostały wymyte w głąb profilu glebowego. Dzięki temu są bardzo dobrym przedplonem zapewniając wysokie plonowanie uprawianych po nich zbóż przy obniżonych dawkach nawozów azotowych. Uprawa roślin bobowatych umożliwia ograniczenie stosowania nawozów pochodzenia mineralnego nawet o $20-25 \%$, co ma znaczenie zarówno ekologiczne jak i ekonomicznie (Prusiński, Kaszkowiak i Borowska, 2018). Według szacunków Komisji Europejskiej (2018) włączenie ich do długoterminowego systemu płodozmianu skutkuje wzrostem plonowania roślin następczych o $10 \%$. W badaniach prowadzonych w Polsce wykazywano nawet 30\% wzrost plonowania pszenicy ozimej uprawianej po przedplonach roślin bobowatych porównaniu do jej uprawy po sobie (Małecka-Jankowiak, Blecharczyk, Sawińska i Waniorek, 2018). Właściwości następcze stanowisk po uprawach bobowatych są wykorzystywane w minimalnym stopniu. Jak wynika $z$ badań prowadzonych w IHAR-PIB w ramach Programu Wieloletniego realizowanego, w latach 2015-2019, procentowy udzial upraw roślin bobowatych wykorzystywanych jako przedplon dla pszenicy ozimej wynosił 7\%. Dzięki korzystnemu oddziaływaniu na strukturę 
gleby rośliny bobowate poprawiają także zdolności zatrzymywania i gromadzenia składników pokarmowych i wody $\mathrm{w}$ glebie, co w ostatnich latach staje się bardzo cenną cechą (Jerzak, 2014, Kapusta, 2017).

Dodatkowo nasiona roślin bobowatych mogą być głównymi zamiennikami śruty sojowej GMO, której import pokrywa 2/3 krajowego zapotrzebowania przemysłu paszowego na białko.

Celem pracy jest ocena stanu i perspektyw produkcji nasiennej roślin bobowatych. Na podstawie trendów $\mathrm{w}$ produkcji towarowej próbujemy określić zapotrzebowanie na materiał siewny, wielkość i wartość rynku nasiennego tej grupy roślin.

\section{Material}

W pracy wykorzystano dane statystyczne publikowane przez Główny Urząd Statystyczny (GUS), dotyczące produkcji oraz cen nasion roślin bobowatych w Polsce oraz dane Instytutu Ekonomiki Rolnictwa i Gospodarki Żywnościowej (IERiGŻ) dotyczące krajowego zapotrzebowania na pasze wysokobiałkowe. Wykorzystano także dane Państwowej Inspekcji Nasiennictwa i Ochrony Roślin (PIORIN) odnośnie wielkości, struktury produkcji nasiennej i obrotu materiałem siewnym roślin bobowatych. Zalecane normy wysiewu potrzebne do obliczenia zapotrzebowania na kwalifikowany materiał siewny poszczególnych gatunków przyjęto na podstawie danych Centralnego Ośrodka Badania Odmian Roślin Uprawnych (COBORU).

\section{Metoda}

Przeprowadzono analizę zmian wielkości produkcji towarowej roślin bobowatych grubonasiennych w wieloleciu 1990-2019 i oceniono istniejące możliwości wzrostu ich produkcji w Polsce.

$\mathrm{Na}$ podstawie wielkości produkcji towarowej roślin bobowatych i wymagań technologicznych, dotyczących zalecanych norm wysiewu, określono zapotrzebowanie na materiał siewny i udział kwalifikowanego materiału siewnego (KMS) stosowanego $\mathrm{w}$ produkcji, a uwzględniając ceny nasion oceniono rzeczywistą oraz potencjalną wartość rynku nasiennego. Określono możliwości dalszego rozwoju produkcji nasiennej w zależności od zmieniającego się zapotrzebowania na nasiona krajowych roślin bobowatych.

\section{Wyniki i Dyskusja}

Wielkość produkcji danej grupy roślin jest zazwyczaj funkcją krajowego zapotrzebowania i możliwości eksportu. W przypadku roślin bobowatych produkowanych na cele konsumpcyjne zapotrzebowanie na kwalifikowany materiał siewny jest ściśle uzależnione od wielkości produkcji towarowej tej grupy roślin i od udziału kwalifikowanego materiału siewnego wykorzystywanego w zasiewach. Względnie stały popyt jest zaspakajany głównie krajową produkcją. Stąd też wahania wielkości produkcji są tu niewielkie i wynikają głównie ze zmian w zapotrzebowaniu na nasiona bobowatych grubonasiennych, kształtowane przez zmieniające się modele odżywiania. Z badań budżetów gospodarstw domowych (GUS, 2017) wynika, że spożycie nasion bobowatych w Polsce jest niskie i wynosi $0,9 \mathrm{~kg} /$ rok/osobę. $\mathrm{Wg}$ danych FAO spożycie jest wyższe, wynosi $1,8 \mathrm{~kg} /$ osobę, co i tak jest znacznie poniżej średniej UE, która wynosi 2,8 kg/osobę (Szczebyło, Halicka, Łuczyńska, 2018). Popularyzacja zdrowego stylu życia, w tym zdrowego odżywiania, rosnąca liczba wegetarian, wegan i osób ograniczających ilość mięsa w diecie będzie czynnikiem wpływającym na zwiększony popyt na nasiona bobowatych jadalnych. W związku z tym można oczekiwać wzrostu zapotrzebowania na nasiona i wiążące się z tym możliwości wzrostu powierzchni uprawy grochu, fasoli, soi na cele jadalne oraz poszukiwanych przez wegetarian i wegan gatunków takich jak soczewica i ciecierzyca. Może to stanowić bodziec do wzrostu popytu na materiał siewny odmian tych gatunków roślin.

Inaczej jest w przypadku roślin bobowatych uprawianych na cele paszowe, gdzie pomimo rosnącego zapotrzebowania na białko roślinne i pasze wolne od GMO oraz korzystnego oddziaływania na zasobność i strukturę gleby i ekonomicznej opłacalności uprawy (Jerzak i Krysztofiak, 2016, Florek, 2017), skala produkcji jest niewielka, a zapotrzebowanie na pasze wysokobiałkowe jest zaspokajane głównie przez import śruty sojowej.

Powierzchnia zasiewów roślin bobowatych pastewnych na nasiona i zielonkę ulega dużym wahaniom w latach. Najwięcej bobowatych pastewnych uprawiano w latach 50 . i na przełomie lat 80. i 90. minionego wieku - blisko 600 tys. ha, a ich maksymalny udział w łącznej powierzchni zasiewów razem z uprawami na zielonkę wynosił około 4\%. W latach 90. powierzchnia uprawy roślin bobowatych w Polsce znacznie się zmniejszyła. Krajowe rośliny bobowate zastąpiono łatwo dostępną i konkurencyjną pod względem cenowym oraz jakościowym importowaną śrutą sojową. Nastąpił spadek, a później stagnacja ich powierzchni uprawy na poziomie $120-130$ tys. ha, czyli 1,1\% łącznej powierzchni zasiewów roślin. 
Podejmowane są próby odtworzenia i zwiększenia ich zasiewów. Od 2004 r. producenci roślin bobowatych mogą korzystać z mechanizmów wsparcia finansowego, tj. jednolitej płatności obszarowej (JPO) i dopłat do wykorzystania elitarnego i kwalifikowanego materiału siewnego, a od 2010 również z specjalnych dopłat do powierzchni uprawy roślin bobowatych. Przychody z uprawy oscylują w pobliżu poziomu opłacalności, stąd też zachęty ekonomiczne $\mathrm{w}$ formie dopłat są istotnym czynnikiem decydującym o ich opłacalności i zainteresowaniu uprawą. Istotne oddziaływanie dopłat na wielkość produkcji roślin bobowatych potwierdzają wyniki badań wskazujące na korelację między wielkością wsparcia a wielkością produkcji (Florek i Czerwińska-Kayzer, 2018). Wprowadzone dodatkowe dopłaty do uprawy bobowatych wpłynęły na zwiększenie powierzchni i udziału w zasiewach do 347 tys. ha co stanowi 3,2\% łącznej powierzchni zasiewów.

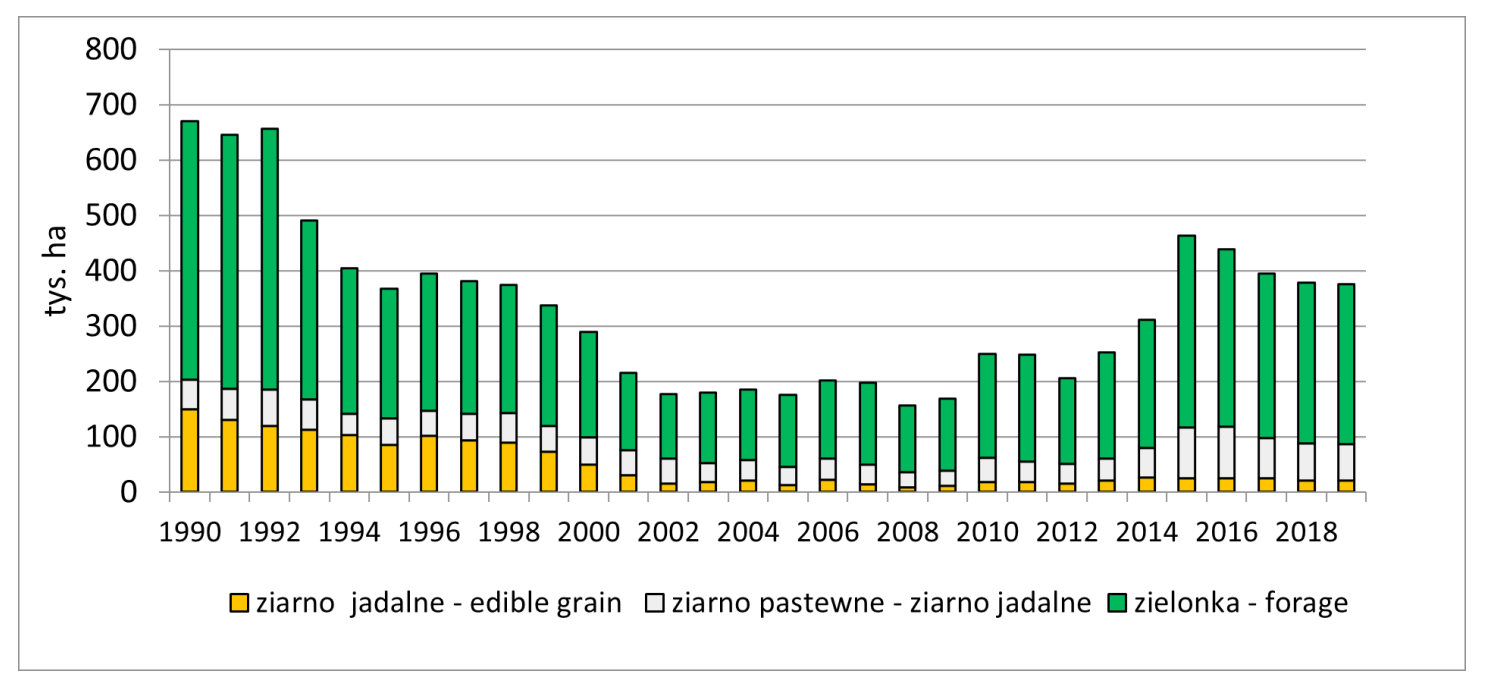

Rys.1 Powierzchnia zasiewów roślin bobowatych grubonasiennych (w tys. ha).

Fig.1 The total cultivation area of grain legumes (in thousand ha).

Wielkość dopłat do 1 ha upraw roślin bobowatych [zl/ha]

The amount of subsidies up to 1 ha of legume cultivation [PLN/ha]

\begin{tabular}{cccccccccccc}
\hline & 2010 & 2011 & 2012 & 2013 & 2014 & $2015^{*}$ & $2016^{*}$ & $2017 *$ & $2018^{*}$ & $2019^{*}$ & $2020^{*}$ \\
\hline $\begin{array}{c}\text { Wielkość dopłat } \\
\begin{array}{c}\text { Amount of sub- } \\
\text { sidies }\end{array}\end{array}$ & 207.4 & 219.5 & 672.6 & 719.4 & 566.4 & 422.0 & 430.5 & 606.5 & 721.0 & 765.8 & 724.4 \\
\hline
\end{tabular}

*) Zgodnie z art.15 Ustawy z dnia 5 lutego 2015 r. o platnościach w ramach systemów wsparcia bezpośredniego od 2015 płatność jest przyznawana rolnikowi do powierzchni upraw roślin bobowatych na nasiona dla gatunków określonych w przepisach wydanych na podstawie art. 34 ust. 1 i 2, jeżeli dokonano zbioru nasion.

Z chwilą ograniczenia dopłat jedynie do powierzchni, z której dokonano zbioru nasion znów obserwowano zmniejszanie się uprawy bobowatych. Obecnie ich udział w łącznej powierzchni zasiewów wynosi $2,7 \%$. Ponad $90 \%$ stanowią uprawy na nasiona, a powierzchnia zasiewów na zielonkę nie przekracza $10 \%$. Spośród uprawianych gatunków największe znaczenie mają groch siewny, łubin i bobik, które stanowią 75\% struktury zasiewów roślin bobowatych wykorzystywanych na cele pastewne.
Spośród bobowatych jadalnych ponad $2 / 3$ upraw to groch i fasola.

Możliwości rozszerzenia powierzchni uprawy roślin bobowatych, warunkowane zapotrzebowaniem na pasze wysokobiałkowe są bardzo duże. Dotychczas wielkość produkcji tych gatunków roślin pokrywa niespełna 7\% krajowego zapotrzebowania na pasze wysokobiałkowe. Warto tu nadmienić, że w naszym kraju blisko $60 \%$ wysokobiałkowych surowców używanych do produkcji pasz stanowi importowana śruta sojowa. 
Zużycie wysokobiałkowych surowców paszowych w Polsce.

Consumption of high-protein feed raw materials in Poland

\begin{tabular}{|c|c|c|c|c|c|c|c|c|}
\hline & $2013 / 14$ & $2014 / 15$ & $2015 / 16$ & $2016 / 17$ & $2017 / 18$ & 2018/19 & $\begin{array}{c}2019 / 20 \\
\text { szacunek } \\
\text { estimation }\end{array}$ & $\begin{array}{c}2020 / 21 \\
\text { prognoza } \\
\text { prediction }\end{array}$ \\
\hline $\begin{array}{l}\text { Razem zużycie } \\
\text { Total consumption } \\
\text { [tys. ton] }\end{array}$ & 3074 & 3621 & 3770 & 3895 & 4349 & 4075 & 4252 & 4410 \\
\hline $\begin{array}{l}\text { Śruty nasion oleistych } \\
\text { Oil seed meal }\end{array}$ & 2767 & 3258 & 3269 & 3475 & 3939 & 3724 & 3880 & 3885 \\
\hline \multicolumn{9}{|l|}{$\begin{array}{l}\text { w tym: } \\
\text { including: }\end{array}$} \\
\hline $\begin{array}{l}\text { Śruta sojowa } \\
\text { Soybean meal }\end{array}$ & 1719 & 2021 & 2311 & 2248 & 2423 & 2383 & 2704 & 2520 \\
\hline $\begin{array}{l}\text { Śruta rzepakowa } \\
\text { Rapeseed meal }\end{array}$ & 596 & 849 & 593 & 858 & 1070 & 941 & 812 & 963 \\
\hline $\begin{array}{l}\text { Śruta słonecznikowa } \\
\text { Sunflower meal }\end{array}$ & 446 & 383 & 360 & 363 & 440 & 395 & 346 & 394 \\
\hline $\begin{array}{l}\text { Pozostałe } \\
\text { Others }\end{array}$ & 6 & 5 & 5 & 6 & 6 & 5 & 19 & 8 \\
\hline $\begin{array}{l}\text { Mączka rybna } \\
\text { Fishmeal }\end{array}$ & 29 & 31 & 35 & 38 & 38 & 38 & 35 & 36 \\
\hline $\begin{array}{l}\text { Nasiona bobowatych } \\
\text { broad bean legumes }\end{array}$ & 278 & 333 & 467 & 383 & 373 & 314 & 337 & 489 \\
\hline \multicolumn{9}{|l|}{$\begin{array}{l}\text { Struktura } \\
\text { Structure [\%] }\end{array}$} \\
\hline $\begin{array}{l}\text { Nasiona bobowatych } \\
\text { Seed of broad bean legumes }\end{array}$ & 9,0 & 9,2 & 12,4 & 9,8 & 8,6 & 7,7 & 7,9 & 11,1 \\
\hline $\begin{array}{l}\text { Śruta sojowa } \\
\text { Soybean meal }\end{array}$ & 55,9 & 55,8 & 61,3 & 57,7 & 55,7 & 58,5 & 63,6 & 57,1 \\
\hline $\begin{array}{l}\text { Śruta rzepakowa } \\
\text { Rapeseed meal }\end{array}$ & 19,4 & 23,4 & 15,7 & 22,0 & 24,6 & 23,1 & 19,1 & 21,8 \\
\hline $\begin{array}{l}\text { Śruta słonecznikowa } \\
\text { Sunflower meal }\end{array}$ & 14,5 & 10,6 & 9,5 & 9,3 & 10,1 & 9,7 & 8,1 & 8,9 \\
\hline $\begin{array}{l}\text { Pozostałe } \\
\text { Others }\end{array}$ & 0,2 & 0,1 & 0,1 & 0,2 & 0,1 & 0,1 & 0,4 & 0,2 \\
\hline $\begin{array}{l}\text { Mączka rybna } \\
\text { Fishmeal }\end{array}$ & 0,9 & 0,9 & 0,9 & 1,0 & 0,9 & 0,9 & 0,8 & 0,8 \\
\hline $\begin{array}{l}\text { Razem zużycie } \\
\text { Total consumption }\end{array}$ & 100 & 100 & 100 & 100 & 100 & 100 & 100 & 100 \\
\hline
\end{tabular}

Żródło: wg Analizy Rynkowe. Rynek pasz - Stan i perspektywy (Dzwonkowski, 2019)

Według International Service for the Acquisition of Agri-biotech Applications (ISAAA, 2021) udzial GMO w światowych zasiewach soi w 2018 roku wynosił $78 \%$, a w krajach będących głównymi eksporterami udział ten przekracza 90\%. Ograniczenie importu śruty sojowej, pochodzącej z upraw modyfikowanych genetycznie odmian i zastąpienie jej nasionami roślin bobowatych uprawianych w kraju, w krótkim czasie, jest możliwe jedynie teoretycznie. Wymagałoby to wielokrotnego wzrostu areału ich uprawy, pomimo wielu istotnych czynników limitujących możliwości rozwoju krajowej produkcji. Ograniczone możliwości całkowitego zastąpienia importowanej śruty sojowej wynikają zarówno z potrzeby znacznych zmian struktury upraw jak i istniejących ograniczeń ekonomicznych związanych z technologicznymi możliwościami substytucji paszy sojowej, a w efekcie spadku wydajności i wzrostu kosztów produkcji zwierzęcej (Niwińska, Szymczyk i Szczurek, 2019).

Zwiększenie podaży nasion roślin bobowatych z krajowych upraw o 2,4 mln ton, bo taka jest wielkość importu soi w ostatnich latach, możemy osiągnąć poprzez wzrost powierzchni ich uprawy jak i wielkości uzyskiwanych plonów. Przyjmując poziom plonowania krajowych roślin bobowatych 
ich plony średnie z 10 lecia 2010-2019 (2,05 dt/ha), to dla uzyskania zbiorów równoważących wielkość importu soi należałoby zwiększyć powierzchnię uprawy o 1171 tys. z obecnych 203 tys. ha do 1374 tys. ha. Przy przyjęciu optymistycznej hipotezy, że uda się odwrócić spadkowy trend plonowania oraz zwiększyć plonowanie o $20 \%$ czyli do $2,45 \mathrm{t} / \mathrm{ha}$, powierzchnię uprawy pastewnych roślin bobowatych uprawianych na nasiona należałoby zwiększyć o 980 tys. ha (rys 2). Skala wzrostu wydaje się nierealistyczna, ale istnieją przykłady porównywalnego a nawet większego wzrostu produkcji. Powierzchnia uprawy kukurydzy na ziarno w Polsce w okresie 1995-2004 wzrosła 9 krotnie, a w okresie 1995-2014 14 krotnie.

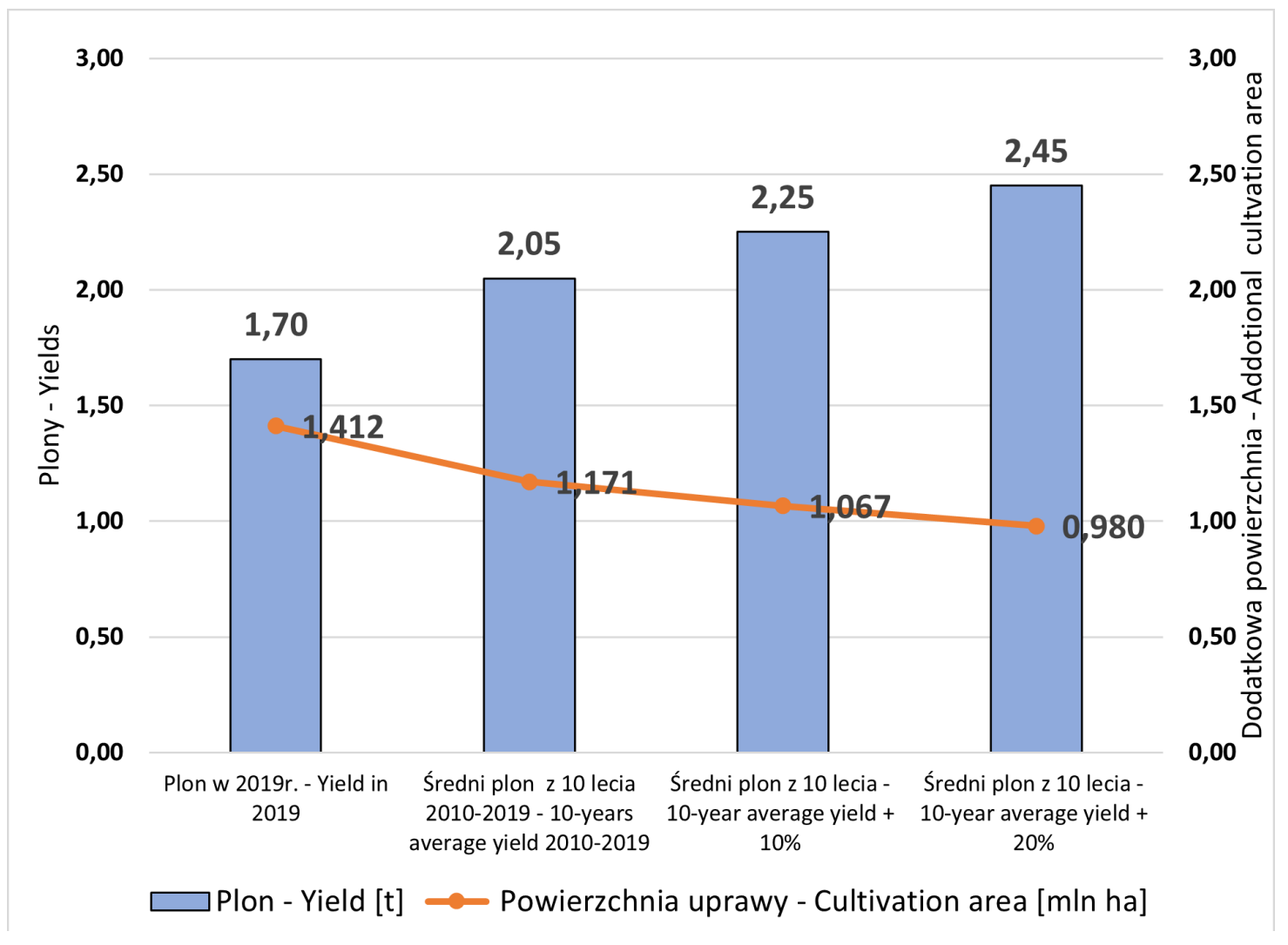

Rys.2 Warianty wzrostu krajowej produkcji roślin bobowatych umożliwiające zastąpienie importu soi.

Fig. 2 Variants of domestic production growth of legumes allowing the replacement of soybean imports.

Bardziej realistyczne wydaje się być zwiększenie areału uprawy roślin bobowatych pozwalające na częściowe pokrycie zapotrzebowania na białko roślinne własną produkcją, podobnie jak to ma miejsce w Niemczech i Francji, gdzie krajowa produkcja roślin białkowych stanowi już 50\% zaopatrzenia $\mathrm{w}$ białko roślinne wykorzystywane w przemyśle paszowym (Bartkowiak-Broda, Boros, Oleksiak i Boros, 2019). W tym przypadku niezbędny byłby co najmniej trzykrotny wzrost zasiewów roślin bobowatych uprawianych na cele paszowe jaki osiągnięto w okresie 2013-2018 w UE (Komisja Europejska, 2018).

Jako główny czynnik ograniczający możliwości wzrostu produkcji upraw krajowych roślin bobowatych, wskazywana jest niekorzystna relacja między kosztami krajowej produkcji, a cenami importowanych nasion. Liczne analizy ekonomiczne wykazują, że możliwa jest ich uprawa zapewniająca opłacalność przy cenach skupu niższych nich ceny importowanej soi (Augustyńska i Bębnista, 2019, Kania, Zając i Śliwa, 2017). Jednak w znacznym stopniu możliwe jest to nie tyle dzięki wielkości zbieranych plonów, a poprzez system dopłat wspierających uprawę. Zmiany w systemie wsparcia wpływają na brak stabilności oraz przewidywalność rynku. Także oczywiste i niekwestionowane korzyści następcze, wynikające z poprawy zasobności i struktury gleby, nie są wystarczająco silnym czynnikiem zachęcającym do uprawy, prawdopodobnie ze względu na znaczne odsunięcie efektów w czasie. Potrzebne są szeroko rozumiane działania marketingowe popularyzujące różnorodne korzyści wiążące się z uprawą bobowatych. Nie mniej istotne niż opłacalność uprawy są trudności logistyczne wynikające $\mathrm{z}$ rozdrobnienia produkcji 
i braku mechanizmów rynkowych zapewniających sprawny system skupu i zaopatrzenia zakładów przetwórczych w ziarno bobowatych. Niewielkie powierzchnie plantacji praktycznie uniemożliwiają dostawy do przetwórni dużych partii surowca, jednolitych pod względem wartości technologicznej. Skup małych partii nasion generuje dodatkowe koszty oraz podnosi cenę surowca (Florek, 2017). Wg GUS w 2019 r. bobowate pastewne uprawiano w 70 tys. gospodarstw co oznacza, że średnia wielkość plantacji w gospodarstwie wynosiła 2,5 ha. Oprócz problemów organizacyjnych istnieją też ograniczenia technologiczne związane $\mathrm{z}$ obecnością substancji antyodżywczych (oligosacharydy z rodziny rafinozy, inhibitory enzymów proteolitycznych trzustki, taniny skondensowane oraz alkaloidy chinolizydynowe), które wpływają na wykorzystanie łubinu i bobiku w mieszankach dla poszczególnych grup zwierząt (Niwińska i in., 2019).

Reasumując, dla zapewnienia znaczącego wzrostu powierzchni uprawy i wielkości produkcji nasion roślin bobowatych istnieje potrzeba zwiększenia skali upraw oraz wykorzystania istniejącego i tworzonego potencjału genetycznego odmian. Możliwe będzie to jedynie przy zdecydowanym wzroście produkcji materiału siewnego potrzebnego do pokrycia zapotrzebowania wynikającego ze zwielokrotnienia powierzchni uprawy jak i zwiększonego udziału kwalifikowanego materiału siewnego używanego przez gospodarstwa rolne.

\section{Produkcja nasienna i sprzedaż nasion}

Powierzchnia zasiewów roślin bobowatych i jej zmiany w czasie wskazują na ocenę sytuacji rynkowej i oczekiwania producentów w zakresie zapotrzebowania na materiał siewny. Rzeczywista wielkość produkcji nasiennej korygowana jest warunkami pogodowymi w okresie wegetacji. Zapotrzebowanie i wielkość sprzedaży materiału siewnego wynika z popytu na nasiona bobowatych i warunków ekonomicznych uprawy. Wielkość zasiewów bobowatych ulega znacznym wahaniom. Po kilku latach stagnacji, zapowiedzi zwiększenia udziału krajowej produkcji roślin bobowatych oraz wprowadzenie mechanizmu dopłat do ich uprawy, wpłynęło na wzrost powierzchni plantacji nasiennych. W latach 2013-2015, ich areał zwiększył się prawie trzykrotnie z 6,5 tys. ha do 18,7 tys. ha, a po uwzględnieniu soi przyrost areału uprawy był jeszcze większy i wyniósł $322 \%$. Dowodzi to, że istnieją mechanizmy umożliwiające zarazem szybki wzrost produkcji jak również jej zmniejszenie, co nastąpiło w kolejnych latach (2016-2018) (rys.3). Lata 2019-2020 to powrót tendencji wzrostowych w zasiewach roślin bobowatych na cele nasienne. W uprawie dominują trzy gatunki; groch, łubin wąskolistny i bobik. W 2020 roku stanowiły one prawie 83,4\%. Znaczące udziały mają też soja $8,2 \%$ i wyka siewna $6,5 \%$. Łubiny żółty i biały oraz wyka kosmata łącznie stanowiły $10 \%$ powierzchni plantacji nasiennych.

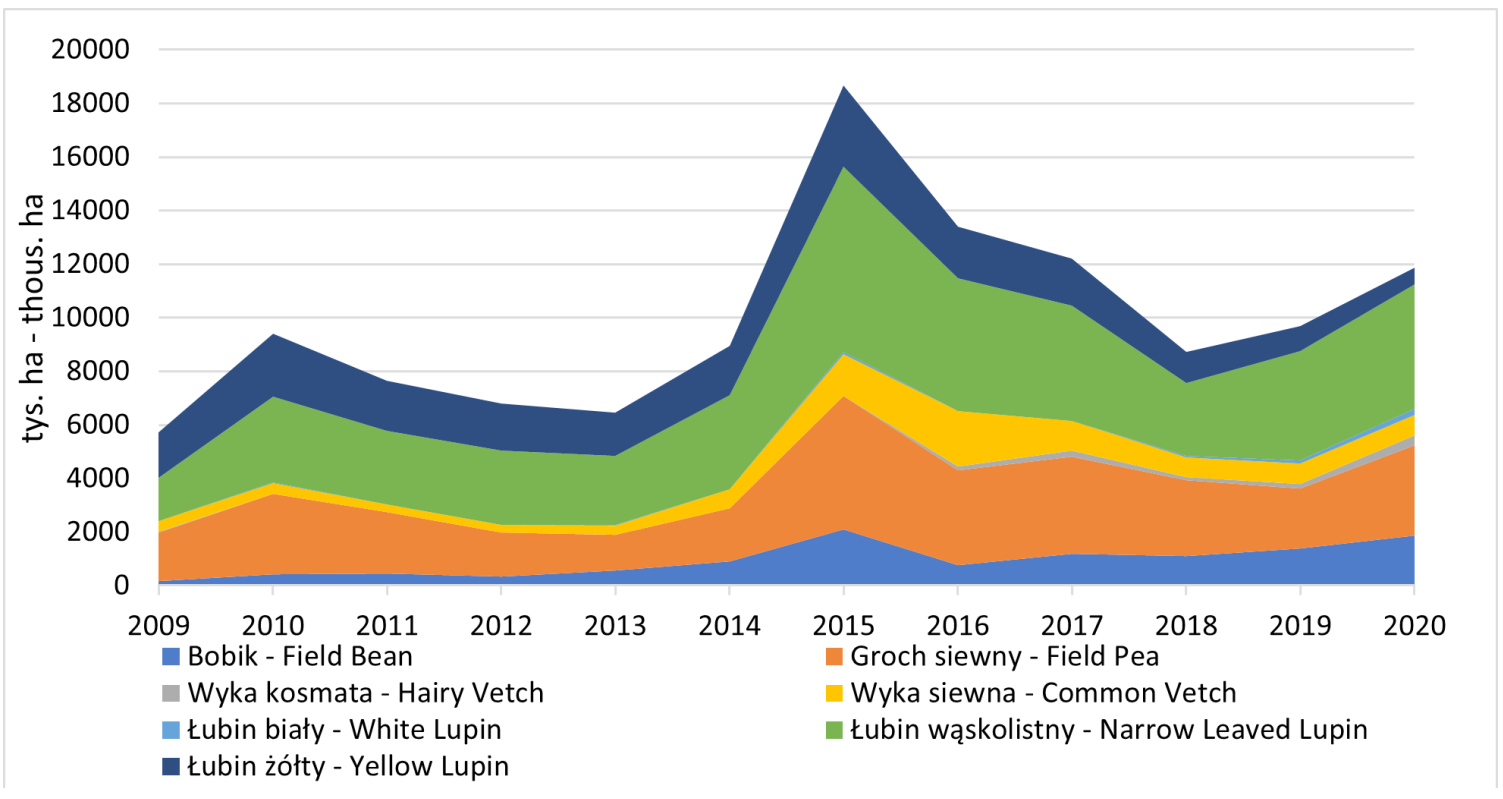

Rys. 3 Powierzchnia plantacji nasiennych roślin bobowatych [tys.ha].

Fig. 3 The area of legume seed plantations [thous. ha]. 
Wielkość produkcji i podaży materiału siewnego roślin bobowatych w Polsce jest głównie funkcją ich plonów i powierzchni zasiewów, ponieważ nasiona znajdujące się $\mathrm{W}$ obrocie pozyskiwane są głównie z krajowych plantacji i sprzedawane na rynku wewnętrznym, a udział importu w strukturze zaopatrzenia jest niewielki. Średni udział importu nasiennego w odniesieniu do łącznej sprzedaży nasion tej grupy roślin w okresie ostatnich 5 lat wynosił $2,7 \%$, jednak widoczne są tendencje wzrostowe. Większe znaczenie ma eksport. Jego udział w łącznej sprzedaży nasion roślin bobowatych wynosił odpowiednio $17,1 \% \mathrm{w}$ wieloleciu i $20,5 \%$ w ostatnim roku. Główne pozycje eksportowe to groch, łubin wąskolistny i wyka siewna, której udział w krajowej produkcji nasiennej jest marginalny i wynosi około $1 \%$, a w strukturze eksportu stanowi aż $20 \%$.
Po kilku latach wzrostu, począwszy od 2015 roku, nastąpił spadek produkcji i sprzedaży nasion. Stymulacja produkcji roślin bobowatych dopłatami nie przyniosła spodziewanych efektów. Produkcja nasienna z 31,4 tys. ton w roku gospodarczym 2015/2016 zmniejszyła się do 12,9 tys. ton w roku 2018/2019. Ostatnie dwa lata to stopniowe odbudowywanie produkcji nasiennej. Zmieniała się struktura gatunkowa produkcji nasiennej. Wzrosły udziały grochu i bobiku, zmalały udziały łubinów żółtego i wąskolistnego. Nasiona trzech gatunków dominujących w uprawie stanowiły ponad $84 \%$ produkcji nasiennej, znaczący jest też udział soi $-8,4 \%$. W wielkości eksportu i importu nasion nie następowały większe zmiany. W roku gospodarczym 2020/2021 wyeksportowano 3,2 tys. ton nasion a zaimportowano 0,5 tys. ton.

Produkcja nasion bobowatych grubonasiennych [tony]

Seed production of legume seed [tons]

\begin{tabular}{|c|c|c|c|c|c|c|c|c|}
\hline & $2014 / 15$ & $2015 / 16$ & $2016 / 17$ & $2017 / 18$ & $2018 / 19$ & $2019 / 20$ & \multicolumn{2}{|c|}{$2020 / 21$} \\
\hline & \multicolumn{6}{|c|}{ Produkcja nasienna [tony] Seed production [tons] } & \multicolumn{2}{|c|}{ Udział Share\% } \\
\hline Bobik - Field Bean & 2546 & 4131 & 1869 & 3073 & 2144 & 2858 & 4529 & 23,6 \\
\hline $\begin{array}{l}\text { Groch siewny - } \\
\text { Field Pea }\end{array}$ & 5121 & 10622 & 6375 & 8000 & 4428 & 5300 & 6752 & 35,1 \\
\hline $\begin{array}{l}\text { Lubin wąskolistny } \\
\text { - Narrow-Leaved } \\
\text { Lupin }\end{array}$ & 7158 & 11173 & 7187 & 4900 & 3463 & 4607 & 4928 & 25,6 \\
\hline $\begin{array}{c}\text { Lubin żółty - Yellow } \\
\text { Lupin }\end{array}$ & 2037 & 1766 & 1700 & 947 & 583 & 399 & 240 & 1,2 \\
\hline $\begin{array}{l}\text { Lubin biały - White } \\
\text { Lupin }\end{array}$ & 15 & 87 & 24 & 28 & 95 & 154 & 142 & 0,7 \\
\hline $\begin{array}{l}\text { Wyka kosmata - } \\
\text { Hairy Vetch }\end{array}$ & 1 & 14 & 51 & 48 & 20 & 67 & 234 & 1,2 \\
\hline $\begin{array}{l}\text { Wyka siewna-- } \\
\text { Common Vetch }\end{array}$ & 827 & 1695 & 1952 & 861 & 629 & 824 & 769 & 4,0 \\
\hline Soja - Soya Bean & 2664 & 1946 & 2120 & 2172 & 1508 & 1410 & 1623 & 8,4 \\
\hline Ogółem - Total & 20369 & 31433 & 21279 & 20028 & 12871 & 15619 & 19216 & 100,0 \\
\hline
\end{tabular}

Wg PIORiN http://piorin.gov.pl/nasiennictwo/ocena-materialu-siewnego/ 


\section{Wartość rynku nasiennego}

Wartość rynku nasiennego danego gatunku rozpatrywać możemy jako łączną wartość wszystkich nasion potrzebnych do obsiania aktualnej powierzchni jego uprawy (potencjalna wartość rynku) lub jako wartość rzeczywistą, czyli wartość kwalifikowanego materiału siewnego zakupywanego i wysiewanego na plantacjach. Przy ocenie wartości rynku rozpatrujemy wartość rzeczywistą.

Udział kwalifikowanego materiału siewnego (KMS) w zasiewach roślin bobowatych jest niski. Relatywnie wysokie są udziały kwalifikowanych nasion soi, wyki i grochu. Wysoki udział KMS wyki wiąże się z relatywnie dużym eksportem jej nasion, natomiast $\mathrm{w}$ przypadku soi może to być wynikiem zaniżonych danych o powierzchni zasiewów tego gatunku. Podobnie jak w przypadku pozostałych gatunków do wyliczeń przyjęto dane GUS, które mogą nie doszacowywać rosnącego zainteresowania tą uprawą i związanym z tym rzeczywistym wzrostem zasiewów. Według GUS w 2019 powierzchnia zasiewów soi wynosiła 7,9 tys. ha. Istnieją jednak szacunki mówiące o znacznie większej powierzchni uprawy. Według agri24.pl już w 2017 uprawiano 15,5 tys. ha soi, wg Koteckiego (2019) soja uprawiana jest na 16,5 tys. ha a wg portalu topAgrar powierzchnia w 2019 wyniosła 20 tys. ha. Nasiona kwalifikowane łubinu wąskolistnego, gatunku najczęściej uprawianego, stanowią $21 \%$, a łubinu żółtego $16 \%$. Średnio jedynie co czwarty hektar upraw roślin bobowatych obsiewany jest kwalifikowanymi nasionami, czyli podobnie jak to ma miejsce w przypadku zbóż (Oleksiak, 2020). Jako minimum zapewniające sprawny transfer postępu hodowlanego i wykorzystanie potencjału biologicznego przyjmuje się 50\% udział KMS co oznacza, że tylko z tego tytułu należałoby co najmniej dwukrotnie zwiększyć aktualne wielkości produkcji i sprzedaży nasion.

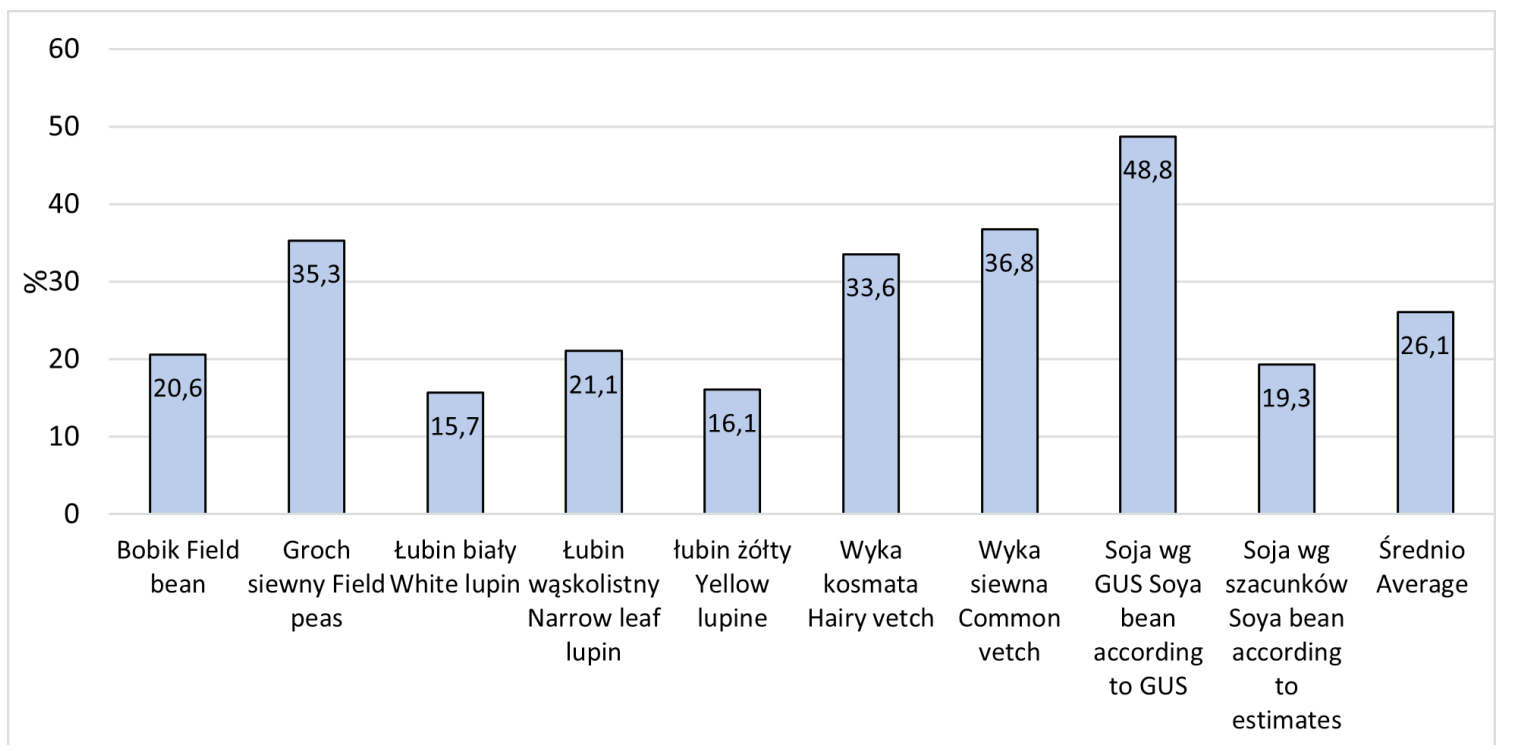

Rys.4 Udział kwalifikowanego materiału siewnego w zasiewach roślin bobowatych in Poland.

Fig. 4 Share of certified seed in grain legume sowing in Poland.

W znacznie większym stopniu na wzrost produkcji i sprzedaży nasion może wpłynąć zwiększenie powierzchni uprawy na cele paszowe, co jest niezbędnym warunkiem poprawy samowystarczalności w zakresie produkcji białka roślinnego.

W zależności od tego jaki przyjmiemy scenariusz produkcji roślin bobowatych i jak skutecznie i konsekwentnie będzie on realizowany, potrzebny byłby wielokrotny wzrost produkcji nasion. Przy przyjęciu realistycznego wariantu wzrostu areału uprawy roślin bobowatych, pozwalającego na 50\% pokrycie zapotrzebowania na białko roślinne produkcją krajową, niezbędny byłby co najmniej trzykrotny wzrost podaży materiału siewnego. Przełożyłoby się to na zwiększenie wartości sprzedaży nasion roślin bobowatych i ich udziału $\mathrm{w}$ krajowym rynku nasiennym z obecnych 2\% (40-60 $\mathrm{mln}$ zf) do poziomu $120-180 \mathrm{mln}$. i przyczyniłoby się istotnie do zwiększenia przychodów i możliwości prowadzenia efektywnej hodowli. Trudno przewidzieć $\mathrm{w}$ jakim kierunku pójdą zmiany struktury upraw bobowatych. Niemniej można zakładać utrzymanie znaczącego udziału łubinów (wąskolistnego i żółtego), predysponowanych do uprawy w Polsce z powodu relatywnie niewielkich 
wymagań glebowych, jak i z powodu wieloletniej tradycji ich uprawy. Perspektywicznym gatunkiem może okazać się soja. Przemawiają za tym zachęcające wyniki badań odmianowych prowadzonych w ramach Inicjatywy Białkowej COBORU wyraźnie wskazujące na duży potencjał wzrostu plonowania nowych odmian tego gatunku w Polsce. Założenia te można opierać na dużym zainteresowaniu producentów, aktualnym znaczeniu nasion tego gatunku jako surowca w przemyśle paszowym jak i jego parametrach jakościowych zgodnych z oczekiwaniem rynku.

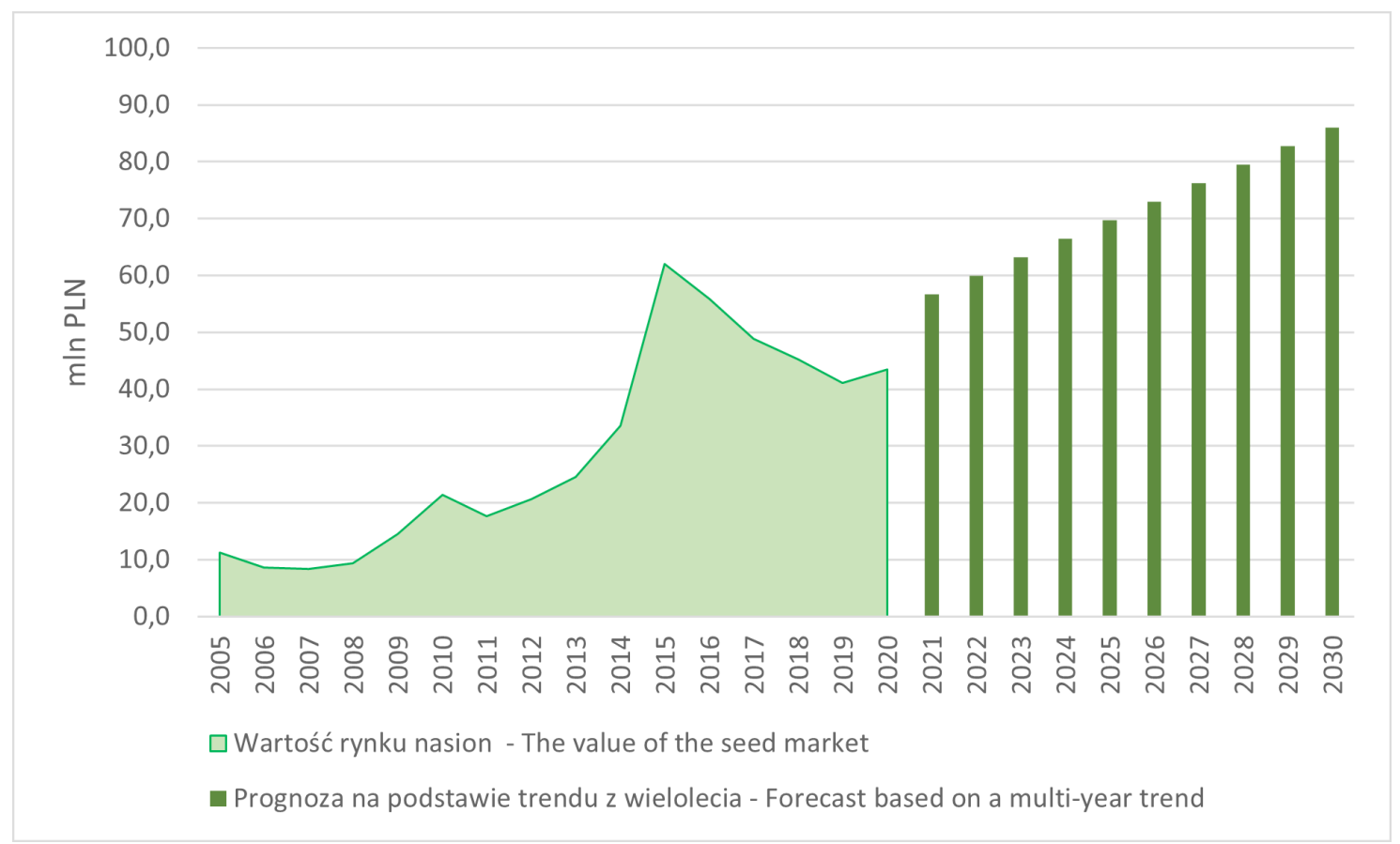

Rys.5 Wartość rynku nasion roślin bobowatych grubonasiennych.

Fig. 5 The value of the grain legumes market.

\section{Literatura}

Augustyńska I., Bębenista A. (2019) Ekonomiczne aspekty uprawy soi i łubinu słodkiego w Polsce. Problemy Rolnictwa światowego tom 19 (XXXIV), zeszyt 2: 256-268 DOI: 10.22630/PRS.2019.19.2.40

Bartkowiak- Broda I., Boros L., Oleksiak T., Boros D. (2019). Stan badań dla hodowli roślin białkowych w Polsce w celu poprawy bilansu białkowego. Biuletyn IHAR, 285, 13-15.

Dzwonkowski W., Łopaciuk W. (2019). Popyt krajowy na surowce paszowe i produkcja pasz przemysłowych. Analizy Rynkowe. Rynek pasz - Stan i perspektywy, 42, $20-26$.

Florek J. (2017). Możliwości wykorzystania roślin strączkowych do produkcji pasz w Polsce. Roczniki Naukowe Stowarzyszenia Ekonomistów Rolnictwa i Agrobiznesu, XIX(4), 40-45.

Florek J, Czerwińska-Kayzer D. (2018). Uwarunkowania rozwoju rynku rodzimych roślin strączkowych w Polsce, Roczniki Naukowe Stowarzyszenia Ekonomistów Rolnictwa i Agrobiznesu, XX(5), 55-61.

GUS (2017) Budżety gospodarstw domowych w 2016 r. Informacje i opracowania statystyczne. ww.stat.gov.pl
ISAAA (2021) International Service for the Acquisition of Agri-biotech Applications https://www.isaaa.org/search/ default.asp

Jerzak M. A. (2014). Możliwości restytucji rynku rodzimych roślin strączkowych na cele paszowe w Polsce. Stowarzyszenie Ekonomistów Rolnictwa i Agrobiznesu, Roczniki Naukowe, XVI(3), 104-109.

Jerzak M. A., Krysztofiak P. (2016). Ekonomiczne możliwości rozwoju produkcji i rynku rodzimych roślin białkowych w Polsce. Stowarzyszenie Ekonomistów Rolnictwa i Agrobiznesu, Roczniki Naukowe, XVIII (2), 130-135.

Kania J., Zając T., Śliwa J. (2017) Efektywność ekonomiczna uprawy soi i rzepaku w zachodniej części Polski. Roczniki Naukowe, tom XVIII, zeszyt 3, 133-138.

Kapusta F. (2017). Rola roślin strączkowych w rolnictwie polskim. Zagadnienia Doradztwa Rolniczego, 1, 68-78.

Komisja Europejska (2018). Sprawozdanie Komisji dla Rady i Parlamentu Europejskiego w sprawie rozwoju produkcji białek roślinnych w Unii Europejskiej. https://eur-lex.europa.eu/legal-content/PL/ ALL/?uri=CELEX:52018DC0757

Kotecki A. (2019). Soja — nowe wyzwania polskiego rolnictwa. Biuletyn IHAR, 285, 49-50. 
Małecka-Jankowiak I., Blecharczyk A., Sawińska Z., Waniorek W. (2018).Wpływ następczy łubinu i grochu na plonowanie pszenicy ozimej w zależności od uprawy roli i nawożenia azotem. Fragm. Agron., 35(4), 67-79. DOI: 10.26374/fa.2018.35.43

Niwińska B., Szymczyk B., Szczurek W. (2019). Perspektywy krajowej produkcji pasz dla zwierząt gospodarskich oraz żywności pochodzenia zwierzęcego bez GMO. Wiadomości Zootechniczne R.LVII(4), 107-120.

Oleksiak T. (2020). Rynek nasion. Analizy Rynkowe. Rynek środków produkcji dla rolnictwa - stan i perspektywy. 47 , 36-43.
PIORIN Obrót materiałem siewnym. http://piorin.gov.pl/ nasiennictwo/ocena-materialu-siewnego/

Prusiński J., Kaszkowiak E., Borowska M.. (2008). Wpływ nawożenia i dokarmiania roślin azotem na plonowanie i strukturalne elementy plonu nasion bobiku. Fragm. Agron., 25(4), 111-127.

Szczebyło A., Halicka E, Łuczyńska K., (2018) Spożycie nasion roślin strączkowych w Polsce jako element modelu zrównoważonej konsumpcji żywności. Prace Naukowe Akademii im. Jana Długosza w Częstochowie, z. XII, s. 35-45 doi.org/10.16926/pto.2018.12.03 